\title{
A study of profit of Musharakah Mutanaqisah homeownership partnership (MMP) by retrospective actuarial approach and simulation study: The case of abandoned housing project
}

\author{
Farhana Syed Ahmad, Shamsul Rijal Muhammad Sabri \\ School of Mathematical Sciences, Universiti Sains Malaysia, 11800 USM, Pulau Pinang, Malaysia \\ Email address: \\ hanatwinn@gmail.com (F. S. Ahmad),rijal@usm.my (S. R. M. Sabri)
}

To cite this article:

Farhana Syed Ahmad, Shamsul Rijal Muhammad Sabri. A Study of Profit and Failure Rate of Musharakah Mutanaqisah Homeownership Partnership (MMP) by Retrospective Actuarial Approach and Simulation Study: The Case of Abandoned Housing Project. Science Journal of Applied Mathematics and Statistics. Vol. 2, No. 6, 2014, pp. 116-121. doi: 10.11648/j.sjams.20140206.13

\begin{abstract}
The paper observed the impact of the profit rate and failure rate to the profit of Musharakah Mutanaqisah Homeownership Partnership (MMP) that exercise in local Islamic Bank in Malaysia while the probability of the housing project's failure is considered into this facility. The retrospective method is a retrospective method of calculating the outstanding balance in actuarial mathematics. Moreover, this study derived a probability of abandoned housing project equations implementing from the actuarial mathematics. The failure rate is assumed to be exponentially distributed. The profit will varies due to the changes of variables like profit rate, failure rate and tenure. This study also presented the intention of IB in bearing the losses of MMP when abandoned housing project occurred.
\end{abstract}

Keywords: Abandoned Housing Project, Actuarial Method, Failure Rate, Outstanding Balance, Profit Rate, Retrospective, Tenure

\section{Introduction}

The practice of housing project in Malaysia is crucial because they implement the 'sell then build' contract. This is believed to be the important factor that leads to the abandoned housing project in Malaysia. In other words, the houses are sold before completion [11]. In June 2005, there were 28 projects which had been listed under the category of abandoned housing project and these involved 5,716 purchasers, 7,946 units of houses and projects in Malaysia [3]. This system let the selling is made from the developer to the purchasers before the houses is complete or before the house is not yet appropriate for occupation and while the houses are being constructed the purchasers need to committed the monthly payment. Asian countries like Hong Kong, Indonesia and Malaysia are practically used this system in their housing trading [16].

Moreover, Malaysia has already involving to this practice extensively since 1980s [17] after more responsible is given to the privates developers to overcome the housing backlog in Malaysia. The system is argued to cause other problems even though the developer claims that this system of sell-then-build had achieved their target in increasing the housing development [12]. The main issue cause from the abandoned housing project is when it involving the Islamic financing system, when the purchasers entrusted the developer for completing the construction within specific time in the agreement [11].Through Islamic Bank (IB), the purchasers is committed on monthly payment until the outstanding financing amount is to be paid and the abandonment of that houses are suddenly occurred during the financing period, and certainly there is an enormous losses will be swallowed. The question remaining here is who is the most right party that will bear all that losses, the IB or the purchasers? The issue became more serious when most of the cases show that the party that will bear the losses is majority from the purchasers that committed into this financing system. Dahlan (2011) has explained in [4] that from the purchaser's perspective, this problem is crucial and as a nightmare for them that had becomes a burdensome social obligation for the government to tackle. In Malaysia, there are two most popular home financing facilities that provided 
by IB. The most popular is Bay'Bithaman Ajil (BBA). However, there are issues arise from implementing the BBA (see [4], [7], [8] and [11]).

The fundamental of BBA concept is indeed very simple. From the initial point of time, the bank would purchase the property from the buyer and resell it at a profit margin to the buyer while the buyer will repay the new purchasing price on the regular installment basis. However the critics on the Bay'Bithaman Ajil (BBA) facility practiced by the Islamic bank (IB) in Malaysia has been raised publically even the Islamic consumer society urged the Central Bank of Malaysia (BNM) to review the legal terms in implementing such facility that was claimed to be prejudice to the purchasers especially in purchasing the properties through Islamic financing facility [8]. The inability of seller to deliver the object of sale to the buyer also forms uncertainty (in this case is the abandoned housing project) in Islam known as gharar al fahish, if this case occurs it will amount to non-delivery of the asset to the purchaser and this will result to the non-compliance of the requirement of subject matter of the contract [11].This is contrary from the Islamic principle which is the main purpose of Islamic economic and finance is to provide human justice and prevent things which are prohibited in Shariah and immorality transaction such as riba (usury), gahrar (uncertainty) and maisir (gambling) [6].

Therefore the scholar and financial advisor suggested the Musharakah Mutanaqisah Partnership (MMP) as the appropriate and suitable facility in replacing the BBA (see [6]). The MMP is a new product in IB which means diminishing partnership. Firstly the contract of MMP is a contract partnership between two parties such as the Islamic Bank and purchaser, where in the end, the purchaser will gradually buys the whole parts of the property [9]. Kuwait Finance House has first offered MMP in Malaysia in 2006 although this contract existed since 1995 [10].

However, from the financier's point of view, there is a certain probability of abandonment of project is considered into the MMP financial system [16]. Therefore in this study, the method of calculating the financing amount with the probability of failure is suggested. See [9] and [10].

\section{Actuarial Approach: Profit Calculation as the Abandonment of the Project is Considered}

\subsection{Actuarial Method Implementation}

The calculation of monthly installment consisting the annuity factor been derived by [2] and [7] is applied in this study. Type of annuity that been used in this is annuity-immediate because the attributes of the financing system is follows the annuity-immediate attributes that the payment of 1 unit each, made at the end of every year or every months for $n$ years and not at the beginning of the years or at the beginning of the months. The monthly of installment $P$ for $n$-years duration of financing at a fixed profit rate, can be viewed as Figure 1.

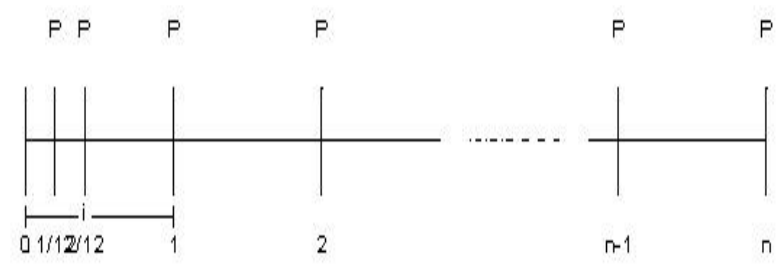

Figure 1. Time-diagram of n-payment annuity-due.

The profit rate is $i$ per payment period assume to be fixed and the financing amount is let by $F$. The installment amount $P$ is to be paid in $n t h$ installment of an annuity immediate is given by (1.1);

$$
12 P=\frac{F}{a_{\left.\bar{k}\right|_{i}}^{(12)}}
$$

The profit rate, $i$ and the amount of financing $F$ are determined in the financing contract. The annuity factor is derived based on known profit/rental rate and duration of financing $k$.

$$
a_{\vec{k} \mid i}^{(12)}=\frac{i}{i^{12}} a_{\left.\vec{k}\right|_{i}}
$$

The installment is calculate based on the annualized percentage rate (APR) of profit or rental rate, $i^{(12)}$ (see[7],[9] and[10]) The calculation of (APR) is shown below;

$$
(1+i)^{12}=1+\frac{i^{(12)}}{12}
$$

\subsection{The Retrospective Method: A Backward Looking Balance of Financing}

Based on the financial mathematics for actuaries study, there are two approaches in conducting the financing balance. The methods are retrospective method and prospective method. The prospective method is forward looking which is the financing balance is calculate as the present value of all future payments to be made. Meanwhile, the retrospective method is backward looking which is the financing balance is calculate as the accumulated of the financing amount at the time of evaluation minus the accumulated value of all installments paid up to the time of evaluation [2]. Moreover, to understand more about the prospective and retrospective method, based on Figure 1, the prospective method is forward looking in time from the base time point, for example if we wanted to calculates the financing amount balance as the present value of all future payment to be made. However, the retrospective method is backward looking, it calculates the financing amount balance that can be considered as profit or losses of bank as accumulates value of financing at the time evaluation minus the accumulated value of all installment paid up to the time of evaluation [2].For examples, if we wanted to calculate the outstanding balance at time 3 , we will consider to the left of time 3 on the time diagram (see Figure.1). This 
study is focus on the retrospective study.

Furthermore, after several case studies, this study assumed that, if the project running smoothly within three years, the project will not fail or have completed and IB will gain profit. However, if within 3 years, if the abandoned housing project is occurring, the project is considered to be fail and the IB will suffer losses. The yearly investment income for MMP can be derived as (4);

$$
k_{k} B=\left\{\begin{array}{c}
{\left[P S_{k}^{(2)}-F(1+r)^{k}\right](1+r)^{n-k} k=0,1 \ldots 3} \\
{\left[P S_{k}^{(1)}-F(1+r)^{n}\right] k>3}
\end{array}\right.
$$

From (4), $B$ is a random variable of the present value from MMP activities of the investment income [9]. Based on equation of (1.4), the upper equation is the amount of profit that IB will gain if the project is complete within 3 years.

\subsection{The Probability of Failure: Abandoned Housing Project Possibilities in the Financial System}

This study involve time or duration, therefore it can always implementing this method which is the time until the event of interest happen can be define as a random variable, likewise this actuarial functions can be used. To conclude, this method is useful in this study to investigate the willingness of the Islamic bank (IB) to bear the losses if the abandoned housing project occurs during the tenure financial. Therefore, the time until the abandoned housing project will be occurring as a random variable.

The probability of failure at initial time $q_{0}$ is defined as $1-e^{-\mu}$ because this study assumes that the probability is following the exponential distribution. Hence, implementing from the actuarial mathematics, the probability of the failure is derived by (5);

$$
\begin{aligned}
& t \approx \exp (\mu) \\
& q_{x}=\int_{0}^{1} \mu e^{-\mu t} \\
& p_{x}=1-\int_{0}^{1} \mu e^{-\mu t}
\end{aligned}
$$

If the abandoned housing project will occur within 3 years in exponentially distributed, from the beginning of the project, we can illustrated that;

For year $1, y_{1} r \exp (\mu, 1)<1$ the housing project will be abandoned at year 1 . The probability of abandoned can be derived as:

$$
q_{k}=\int \mu e^{-\mu t} d t
$$

For year $2, y_{2} r \exp (\mu, 2)<1$ the housing project will be abandoned at year 2 . The probability of abandoned can be derived as;

$$
P_{k} q_{k+1}=\left(1-\int_{0}^{1} \mu e^{-\mu t} d t\right)\left(\int_{0}^{1} \mu e^{-\mu t} d t\right)
$$

For year $3, y_{3} r \exp (\mu, 3)<1$ the housing project will be abandoned at year 3 . The probability of abandoned can be derived as;

$$
P_{k} q_{k+2}=\left(1-\int_{0}^{1} \mu e^{-\mu t} d t\right)^{2}\left(\int_{0}^{1} \mu e^{-\mu t} d t\right)
$$

Therefore after 3 years if there is no failure or abandonment occurs to that particular housing project, it can be assumes that the housing project under construction will be successfully built. Hence the probability of success or not abandoned can be derived as;

$$
3 P_{k}=\left(1-\int_{0}^{1} \mu e^{-\mu t} d t\right)^{3}
$$

These equations of financing amount and the probability of failure are then encoding into a simulation study, to experiment the outcomes of this method.

\section{Simulation Modeling: Study the Impact of Failure Rates and Profit Rates}

\subsection{Algorithm of the Simulation Model}

The simulation steps and the algorithms are as follows;

1. The input of the parameters that are encoding in the simulation model are as follows;

i). $F$ as the financing amount of RM200, 000

ii). $n$ as the term to be paid of 20 years.

iii). $i$ as the profit rate in monthly figure is,

$$
\begin{aligned}
i^{(12)} & =12\left[(1+i)^{1 / 12}-1\right] \\
& =0.058410606
\end{aligned}
$$

iv). $r$ as the monthly rate of return of bank is, $r^{(12)}=12\left[(1+r)^{1 / 12}-1\right]$

$$
=0.029595237
$$

v). The monthly installment is of P (see (1),(2),(3) and (4)).

vi). The probability of the abandoned housing project (see (5),(6),(7),(8) and (9))

vii). The profit of the bank after considering the abandoned housing project ( see (4))

2. The bank is funding about $m$ number of debtors which are 100 debtors, and the step of 1-2 is repeated for $m$ debtors.

3. The above study is again repeated for 100 times to obtain 100 values of the bank's profit.

4. If the what-if analysis is conducted, and the step of 1-3 is repeated for every what-if analysis.

5. Plot graph and finding. 


\subsection{What-If Analysis of the Profit}

This study expends the analysis to what-if analysis which is usually done by researcher to capture the impact or the sensitivity of the simulation model. The variables that interested in this experiment are the profit rate $(i)$, failure rate $(\mu)$ and tenure.

The profit will affected by varies of profit rates $(i)$ and failure rates $(\mu)$. Let assume the tenure is fixed by 20 years and the rate of return is fixed by $r^{(12)}$. (See chapter 3.1). The what-if analysis of the profit rate will consider the monthly profit rate $\left(i^{(12)}\right)$ from $4 \%$ until $0.8 \%$ for every failure rate $(\mu)$. The failure rate is exponentially distributed in every year as shown in Table 1.

Table 1. The probability of failure of exponential distribution.

\begin{tabular}{lllllll}
\hline $\boldsymbol{\mu}$ & $q_{0}$ & ${ }_{17} q_{0}$ & ${ }_{27} q_{0}$ & ${ }_{37} q_{0}$ & $q_{0}$ & \\
\hline 0.01 & 0.0100 & 0.0099 & 0.0098 & 0.0097 & 0.0096 & 0.9512 \\
0.02 & 0.0198 & 0.0194 & 0.0190 & 0.0186 & 0.0183 & 0.9048 \\
0.03 & 0.0296 & 0.0287 & 0.0278 & 0.0270 & 0.0262 & 0.8607 \\
0.04 & 0.0392 & 0.0377 & 0.0362 & 0.0348 & 0.0334 & 0.8187 \\
0.05 & 0.0488 & 0.0464 & 0.0441 & 0.0420 & 0.0399 & 0.7788 \\
0.06 & 0.0582 & 0.0548 & 0.0517 & 0.0486 & 0.0458 & 0.7408 \\
0.07 & 0.0676 & 0.0630 & 0.0588 & 0.0548 & 0.0511 & 0.7047 \\
0.08 & 0.0769 & 0.0710 & 0.0655 & 0.0605 & 0.0558 & 0.6703 \\
0.09 & 0.0861 & 0.0787 & 0.0719 & 0.0657 & 0.0600 & 0.6376 \\
0.10 & 0.0952 & 0.0861 & 0.0779 & 0.0705 & 0.0638 & 0.6065 \\
\hline
\end{tabular}

\section{Finding and Analysis}

After several replications, the result obtained is being analyzed. The main outcome of the simulation study find out that as the $\mu$ is increasing; the profit of rate is decreasing. The tenure also plays an important role, because the profit is increase as the tenure is increasing. For better understanding, please refer to the graph below;

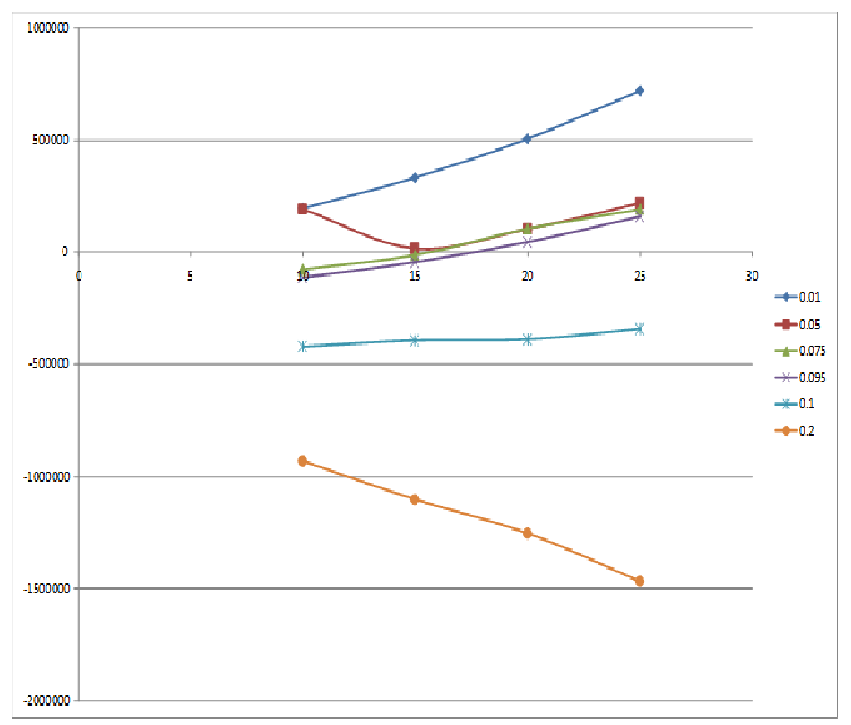

Figure 2. The profit when the $\mu$ are from $0.01,0.05,0.075,0.1$ and 0.2 . The tenure is from 10 to 25 years, with the fixed profit rate of $6 \%$, fixed rate of return of 3\% and same financing amount of RM200, 000.

This is the main reason why the IB prefers to provide the financing in a longer tenure, because the longer the tenure the better profit they will gain. From the graph, it can be conclude that probability of abandoned housing project is an important variable that should be consider in this study because it have a great impact to the profit earning. The correlation of profit and $\mu$ shows in this study is -0.7412592 , which means there is a statistically significant negative relationship between the failure rate of $\mu$ and the profit obtained.

The what-if-analysis result obtained in this study is shown in Figure 3 below;

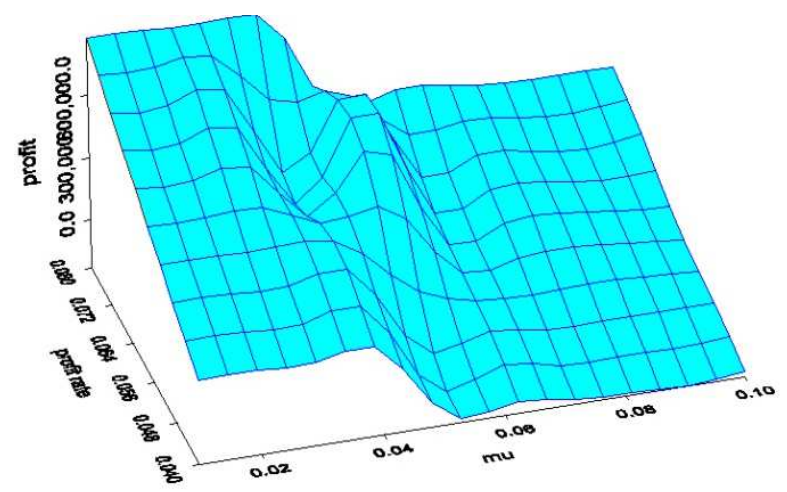

Figure 3. The 3D-illustration of the impact of the profit rate to the profit with varies rate of return from (0.01 to 0.1), fixes rate of return of $3 \%$ and fixed tenure of 20 years, with same financing amount of RM200, 000.

From Figure 3 above, at profit rate of $4 \%$, the IB will earns profit almost at RM $200 \mathrm{~K}$, however the IB will loses when the $\mu$ is nearly 0.05 , the losses suffer by IB is increase drastically at $\mu$ between 0.05 and 0.06 and at $\mu$ between 0.07 to 0.09 . At profit rate $5 \%$, with $\mu$ in between 0.01 to 0.02 , the IB will gain profit almost RM350K, at this state, the profit is increase significantly, however the profit is maintain a constant amount of RM350K in between $\mu$ from 0.02 to 0.05 , the profit start to decrease severely at $\mu$ is 0.05 and the losses start to occur in between $\mu 0.06$ to 0.1 . However the losses are not excessively as when the profit rate $4 \%$. At profit rate is $6 \%$, the IB will continuously earns profit at $\mu=0.01$ until $\mu=0.06$, however, because of the failure rate increase at $\mu=0.08$, the profit is decreasing. The amount of the decreasing profit is not negative but nearly to zero profit. Besides, it cannot be concluding that the IB will not suffers from the losses; the IB is still suffering from the losses if there is no profit gain to do the investment. The situation is similar when the profit rate at $7 \%$. At profit rate $8 \%$ the IB is 
always gain the profit even though the probability of abandoned is still there, the profit of IB can increase until $900 \mathrm{~K}$ at $\mu$ until $\mu=0.04$, and decreasing until RM400K at $\mu=$ 0.05 until $\mu=0.1$. However this rate of profit is too high for IB to implementing into this MMP facility with the rule and limitation from the Bank Negara and also Islamic scholar (see Figure 4).

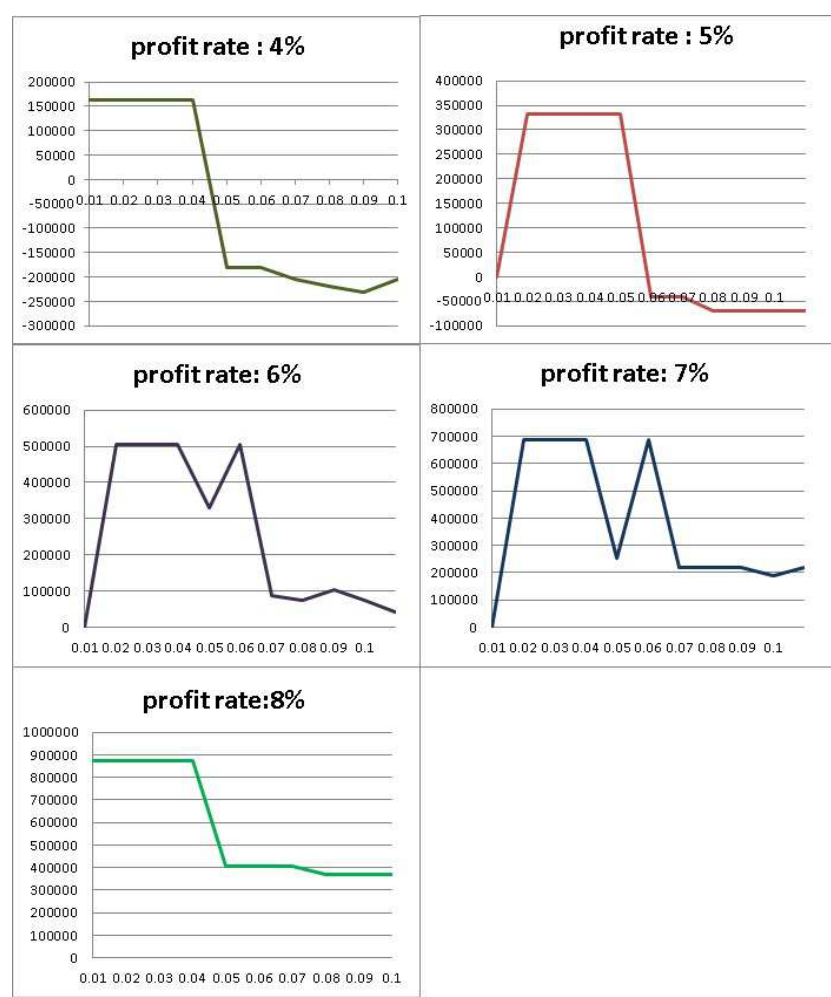

Figure 4. The 2D-illustration of the impact of profit rate to the IB's profit provided MMP facility when considering the abandoned housing project probability. The $y$-axis is the profit gain in (RM) and the $x$-axis is the value of failure rate $(\mu)$.

\section{Conclusion}

The main purpose of Islamic financing system is to avoid the riba or usury that was practice by conventional bank which provided a loan to the debtors with condition to pay back with excess money called riba. Furthermore, the Islamic finance must both be legitimate and ethical which is to bring about justice and compassion among people. From the cases study in Malaysia, most debtors or purchasers of houses under construction were disappointed with the Islamic banking system because of the abandoned housing project that suddenly occurred. IB should not let the debtors to face the losses alone and demanding their payment, because each of the parties responsible for selling the rights which failed to completed in a duration. They have to suffer the losses and facing more difficulties to solve the problem legally. In this situation, if the Islamic bank have an enough information and abilities to figure out the failure rate or the probability of the abandonment of the project and forecast the profit and losses before they decided to providing the contract of the financing product, the graveness of losses from abandoned housing project could be prevent.

The previous study conclude that IB has right to increase their profit rate [8] because unlike the conventional bank, Islamic bank (IB) is responsible to the losses from the abandoned housing projects because they implementing the Islamic trading. There is verse in [1] (2:280) mentioned that it is noble for the financier to bear the loss due to the abandoned housing project. However, there is no specific method to calculate this particular risk and its information. There is a rational objective from the financier's point of view to find a way on how to bear the losses due to the abandoned housing projects issue. The implementation of actuarial mathematics in this study contributed a significant method in calculating the profit from both retrospective and prospective ways to the Islamic financing system when the risk of abandonment is taking into account. However this study is focusing on the retrospective method. In this study, the IB will be able to investigate the suitable profit rate for a certain failure rate, therefore even though the financing provided will accountable by the IB, they should already be prepared and manageable even though the failure may occurred in any time.

\section{References}

[1] AL-QURAN. (n.d.).

[2] Chan, E. H., \& Tse, R. Y. (2003). Cultural Consideration in International Construction Contracts. Journal Of Contruction Engineering And Management (ASCE).

[3] Chau, K. W., Wong, S. K., \& Yiu, C. Y. (2007). Housing Quality in Forward Contract Marketing. Springer Science + Business Media, LLC.

[4] Dahlan, N. H. (2011). Legal Issues in the Rehabilitation of Abandoned Housing Projects of the Liquidity HousingDeveloper-Companies in Penisular Malaysia. European Journal of Social Science Vol 23 Number 3 , 392-406 .

[5] Hoe, Y. E. (2013). Causes of Abandoned Construction Projects in Malaysia. University Tunku Abdul Rahman(UTAR).

[6] Iqbal Z., M. A. (2007). An Introduction to Islamic Finance: Theory and Practise. John Wiley \&Sons.

[7] Kellison, S. G. (2005). The Theory of Interest Second Edition. McGraw Hill .

[8] Md.Dahlan, H. N. (2008). In Need to define 'Abandoned Housing Project' In Peninsular Malaysia: An Analysis. IIUM LAW JOURNAL, Vol 16. No 1.

[9] Sabri, S. M. (2013). The Willingness of Musharakah Mutanaqisah Partnership in Bearing the Loss- By Actuarial Approach to evaluate the Bank Investment Income by the Case of Abandoned Housing Project. Journal of Emerging Technologies in Web Intelligence, 117-121.

[10] Sabri, S. M., \& Ahmad, F. S. (2014). A Retrospective Study of the Behavior of Profit in Musharakah Mutanaqisah Partnership Home Ownership (MMP) By the Case of Abandoned Housing Project. Proceedings of the 21st National Symposium on Mathematical Science (SKSM21) (pp. 1067-1072). AIP Publishing . 
[11] Salman, S. A., \& Nu Htay, S. (2011). Is Any Defect on Islamic Product: A Case Study of BBA. Retrieved from ire.iium.edu.my.

[12] Salman, S. A., \& Nu Htay, S. N. (2011). Is Any Defect In Islamic Banking Product? A case Study of BBA.

[13] Salwani, R. (2008). The Principles of Gharar In Bai Bithaman Ajil Contract. Proceeding of The MFA Conference, (pp. .400-437).

[14] Salwani, R. (n.d.). The Principle of Gharar In Bai Bithaman Ajil Contract.

[15] Shahwan, S., Muhammad, M. O., \& Abdul Rahman, Z. (2011). Home Financing Price Issue in The Bai' Bithaman Ajil (BBA) and Musharakah Mutanaqisah (MMP). GJAT , 23-36.
[16] Taib, F. M., Ramayah, D., \& Razak, A. (2008). Factors influencing intention to use Diminishing Partnership Home Financing. International Journal; of Islamic and Middle Eeastern Finance and Management Vol.q No.3, 235-248.

[17] Teoh , A., \& Lim , E. L. (2011, March 22). A Banker's Perspective. The Association of Banks in Malaysia. Retrieved from http://www.abm.org.my/BuildThenSellConcept;ABanker\%E2 $\% 80 \% 99$ s_Perspectives.aspx

[18] Yusof, N. M. (1997). Strategies to Implement the 'Build Then Sell' housing delivery system in Malaysia. Hbaitat International 34(1), 53-58 